\title{
THE SPATIAL LATTICE DESIGN FROM A TETRAPOD-SHAPED ELEMENT
}

\section{TELPISKA REŽĢA KONSTRUKCIJAS NO ČETRZARA ELEMENTA}

E. Bervalds, Dr.sc.ing., Project Leader, Latvian Academy of Sciences, Akademijas laukums 1, Riga LV-1050, Latvia, berv@acad.latnet.lv

O. Verners, M.sc.ing., Researcher, Department of Computer Aided Engineering Graphics, Riga Technical University, Azenes St 16/20, Riga, LV-1048, Latvia, Osvalds.Verners@ rtu.lv

M. Dobelis, Dr.sc.ing., Professor, Head of Department of Computer Aided Engineering Graphics, Riga Technical University, Azenes St 16/20, Riga, LV-1048, Latvia, Modris.Dobelis@rtu.lv 
Keywords: Tetrapod, Tessellation, Lattice, Geometry, Topology

\section{Introduction}

Two discoveries allow fundamentally diverse structural systems with hexagon-type lattice to be offered for the synthesis of minimum mass and maximum stiffness constructions [1-3]. The first lies within structural mechanics for the solving of an optimal lattice problem and the second within structural geometry for the solving of an optimal 2-dimensional multiscale tessellation problem. The highest efficiency of both mechanical and geometrical properties could be achieved using hexagontype spatial rigid bar structures built from tetrapod-shaped structural elements, further referred to as superelements. Due to lightweight considerations, the superelements can be modeled as shell structures. Unexplored, however, remain the topological transformations and multiscale tessellation possibilities of regular spatial lattices in analogy to the 2-dimensional transformations considered so far [1-3]. Therefore, this article will concentrate specifically on derivation of hexagon-type spatial lattices, based on knowledge that is available from the 2-dimensional lattice definitions. Similarly, the multiscale tessellation compatibility possibilities of the spatial lattice cells will be explored on the basis of 2-dimensional studies.

\section{Geometric definition of the superelement}

The tetrapod-shaped superelement could be derived by topological transformations of spatially arranged spheres analogously to circles considered in [1]. An alternative and more straightforward approach to obtain the superelement could be the analytic geometric definition of a spatial rayed structure which would have equal angles between any pair of rays. This yields a four-ray star element, also named tetrapod, in analogy with the three-ray star element in a two dimensional problem [1]. The angle $\beta$ between any pair of rays is estimated according to (1):

$$
\beta=2 \arccos (1 / \sqrt{3}) \approx 109.5^{\circ},
$$

where $\beta$ - angle between arbitrary superelement leg pairs (angle beta in Fig. 1).

An analogous structure known from chemistry is the tetrahedron molecular building block [5].

The topological relation of the spatial superelement to the 2-dimensional one can be seen in the top view of the element (Fig. 1), which is the only fully regular orthogonal projection in the standard three-view set of the superelement.

\section{Lattice variants}

In order to determine the shapes of the regular spatial lattices that would correspond to spatial analogues of hexagonal lattices for the 2-dimensional case (Fig. 2), again two choices are available. The first one is to apply topological transformations to spheres, located at regular points in space [1]. The second one is to search for all unique combinations of the superelements. However, both of the approaches ask for proof that all possible lattice configurations have been found. Alternatively, as a combined approach, it is possible to use the 2-dimensional hexagonal lattice as a starting point for expanding to three dimensions (see also [6]). This allows employing the fact that only one unique configuration of circle center points exists for the 2-dimensional case [1]. Additionally keeping in 
mind that only one unique regular projection of the superelement is available (see above), two spatial hexagon-type cell analogues (Fig. 3) and, consequently, two lattice variants (Fig. 4) can be constructed. Their uniqueness can be explained by considering three imaginary spheres, located at grid points of an imaginary regular planar triangular lattice (single surface cuts are shown in top views of Fig. 3) and having the radius of doubled length $R$ of a superelement ray. The spheres, which represent topological transformations of tetrapod-shaped elements, have contiguous points, which coincide with two other identical plane lattices, shifted by doubled height $h$ (as defined in Fig. 1) vertically and in-plane. This results in two unique lattice cell variants. The first one is found to be symmetric with respect to a horizontal plane (Fig. 3 a), whereas the second one is not (Fig. 3 b). It can be easily verified that the two vertically shifted triangular lattices are related by a $60^{\circ}$ rotation around a vertical axis through an arbitrary point of the initial lattice. Note that both cell variants share the same lower part, which corresponds to a hexagon in the top view. Likewise, the top view also corresponds to the unique regular projection of the superelement.

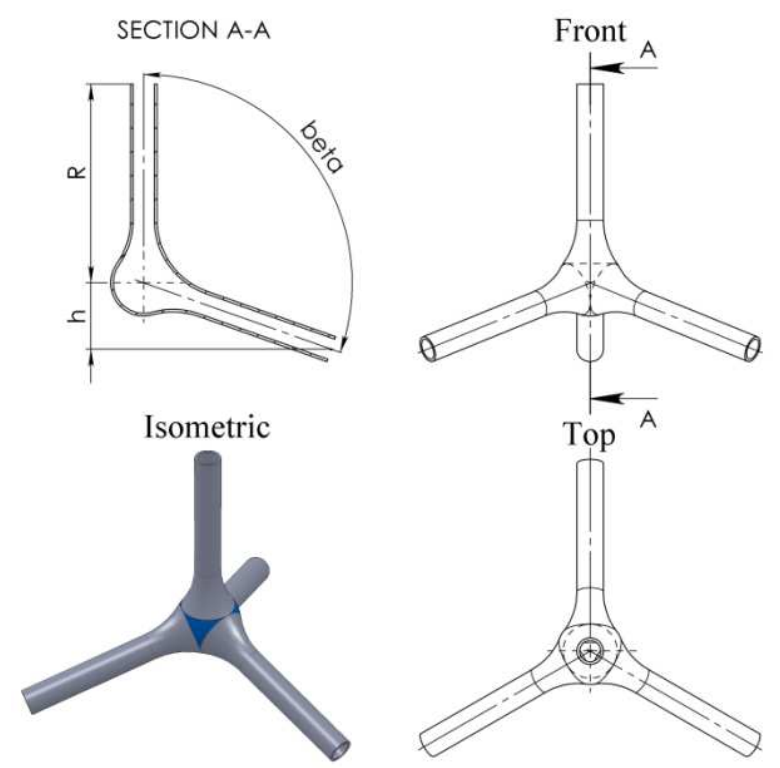

Fig. 1. Superelement model

\section{Lattice expansions}

First, a simple observation of the orthogonal lattice projections reveals that the first lattice variant has symmetry planes parallel to the horizontal plane (Fig. 4 a), whereas the second variant has a symmetry plane (Fig. 4 b) at an angle $\gamma \sim 35^{\circ}$ with the horizontal plane according to (2):

$$
\gamma=\arcsin (\cos (\beta) / \cos (\beta / 2)) \approx 35.3^{\circ},
$$

where $\gamma$ - angle between the symmetry planes and the top plane of the second lattice variant (angle gamma in Fig. 4 b).

Also, considering the analogy to the 2-dimensional hexagonal lattices, as obvious from the top views, the first variant shows that horizontal hexagonal layers, which actually vary in height by $2 h$ for a single layer and by $2 R$ between consecutive layers perpendicularly to the top (horizontal) planes (Fig. 1), remain parallel to each other, whereas for the second variant the layers are alternately shifted to the center points of contiguous layers. This raises the question of whether alternative superelements can be found which would account for the differences between the lattices (see below). 


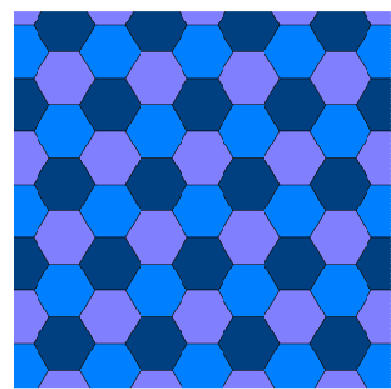

Fig. 2. 2-dimensional hexagonal lattice (honeycomb)

a)
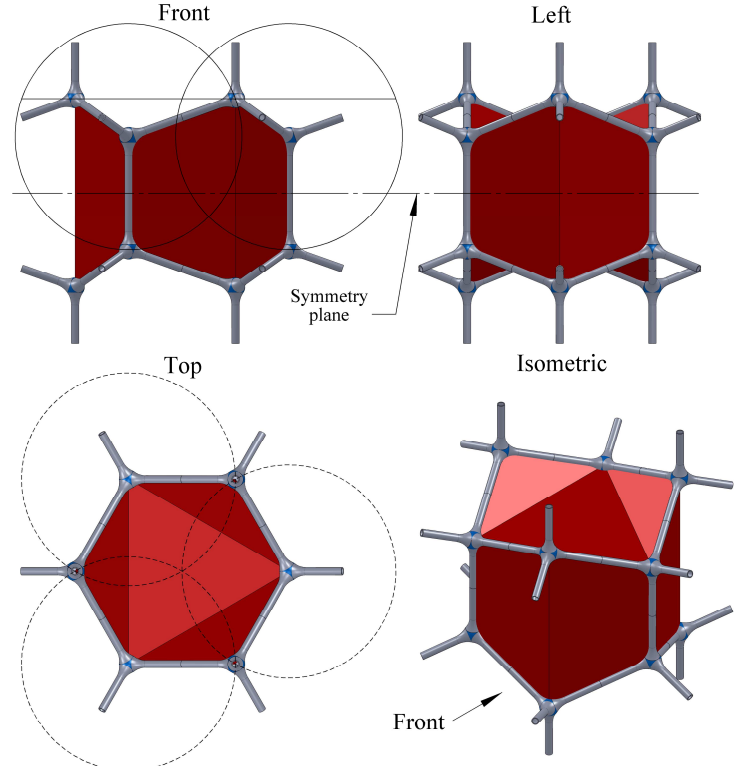

b)
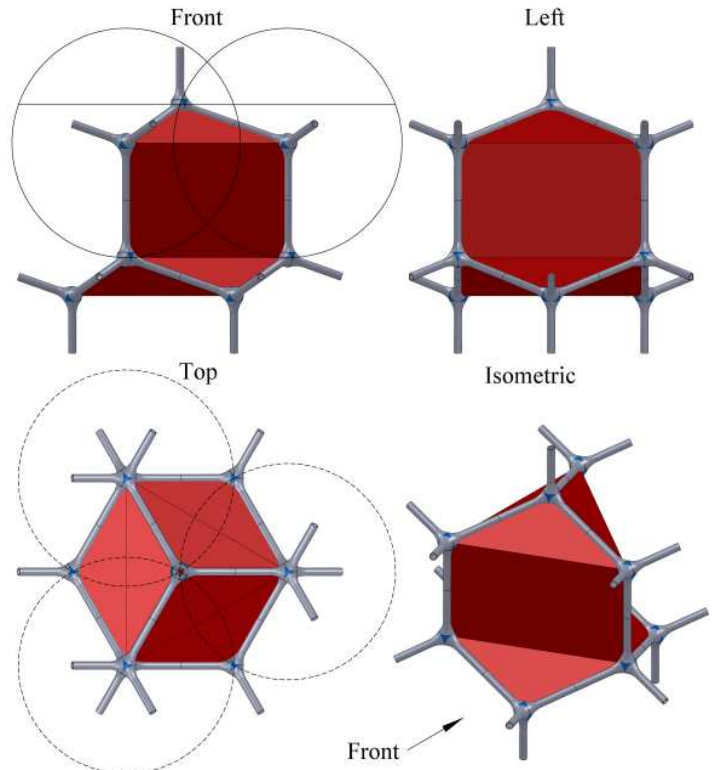

Fig. 3. Two cell variants of spatial hexagon-type cell analogues: a - symmetric with respect to a horizontal plane $\mathrm{b}-$ non-symmetric with respect to a horizontal plane 


\section{Multiscale tessellation possibilities}

For a further level of abstraction, it is possible to represent the cells in a surface body form (Fig. 3), which allows for considering multiscale tessellation of the lattices. This would allow taking into account the multiscale tessellation characteristics discussed in [3] for the 2-dimensional case, which corresponds to the top view of the lattice.

According to [3], in any hexagon circumscribing a single cell of larger scale (top view), the ratio of radii between consecutive scales being 1:2, its vertices coincide with vertices of initial scale lattice hexagons. An examination of vertex coincidence for the spatial lattices of different scales in the standard orthogonal projections reveals that repeating patterns do exist (defined as ratios dil:di2 in Fig. 5, where $i-a, b, c, d, e$ ). However, there arise differences for each lattice variant. For the first one full coincidence could not be found within the range of 1:4 (see the lack of coinciding points in the left view of Fig. 5 a), whereas for the second one it was found to be 1:3 (Fig. 5 b), thus proving this variant to be of advantage for multiscale tessellation purposes. The increase of edge ratio compared to the 2-dimensional case is supposedly due to lack of regularity, which is observable only in the top views.

\section{Alternative superelement choice consideration}

Due to the two different combination possibilities of the currently defined superelement there can be distinguished two unique alternative superelements. The first one (Fig. 6 a) is unique to the first lattice due to its symmetry with respect to a horizontal plane. Accordingly, it features a single cyclically symmetric ray cut out of the initial superelement (Fig. 1), which has consequently been mirrored around the plane of its circular outer edge. The element can be considered as a linking element between consecutive hexagonal layers located parallel to the top (horizontal) plane (Fig. 4 a). The second superelement (Fig. 6 b), for its part, is shared by both cell variants as a result of the similarity in the lower parts of the cells (Fig. 3). Its structure is obtained by the same procedure as the first one with an additional rotation of the mirrored part by $60^{\circ}$ around the central axis of the cut-out ray (refer to the similar relation between the two lattice variants mentioned above). The second lattice employs the second superelement also as the linking element (Fig. 4 b), which renders the corresponding lattice structure more homogenous from both geometric and mechanical points of view.

\section{Outlook}

In order to provide an exact surface shape definition for the superelement, a mechanically determined geometry optimization of the superelement should be carried out. For this task, one option beside topology and parameter optimization in general is the shape optimization, which requires a parameterized geometric model of the element.

Shape optimization also requires certain assumptions regarding the expected optimum shape of the geometry to be optimized. These include a continuous structure, revolution surface shape for the rays specifically and an increase of the outer ray diameter towards the element center because of a supposed stress concentration in the joint part of the elements.

Generally, all the shape assumptions can be met by implementing NURBS curves and surfaces. However, no specific information regarding the optimum superelement shape being available for the time being, a specific proposal, which would allow easy parameterization, is to describe the element shape by possibly the simplest geometric shapes that would conform to the initial shape assumptions [4]. The proposed shapes include a sphere in the center of the element, which is joined through constant radius fillets, corresponding to toroidal surfaces, with the four rays, represented by conical surfaces, which are likewise being joined with the rays of other contiguous elements by constant radius fillet transitions (Fig. 7). Such element geometry parameterization model corresponds to a set of five independent parameters subject to constraints imposed by the initial shape assumptions and geometric compatibility. 
a)
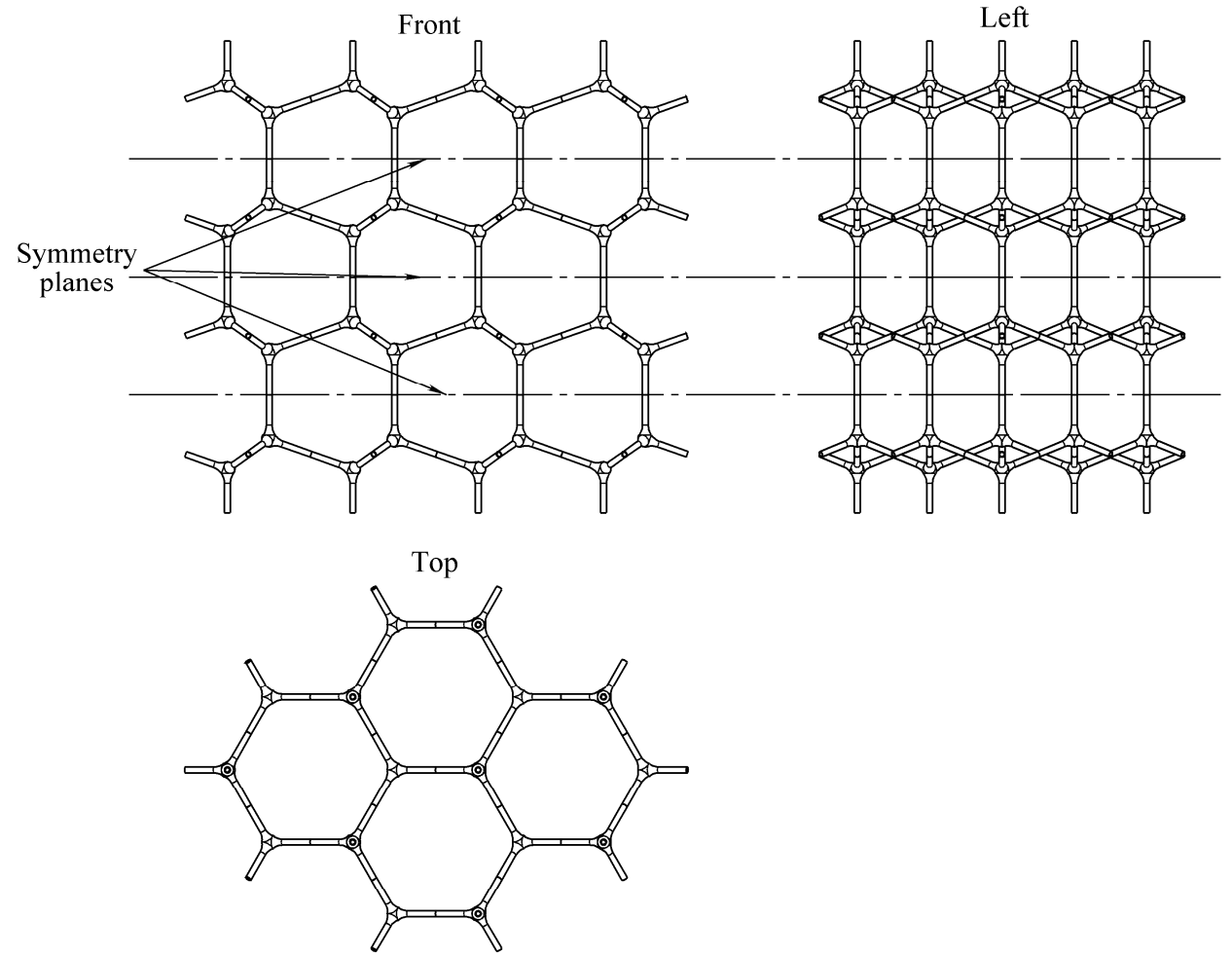

b)
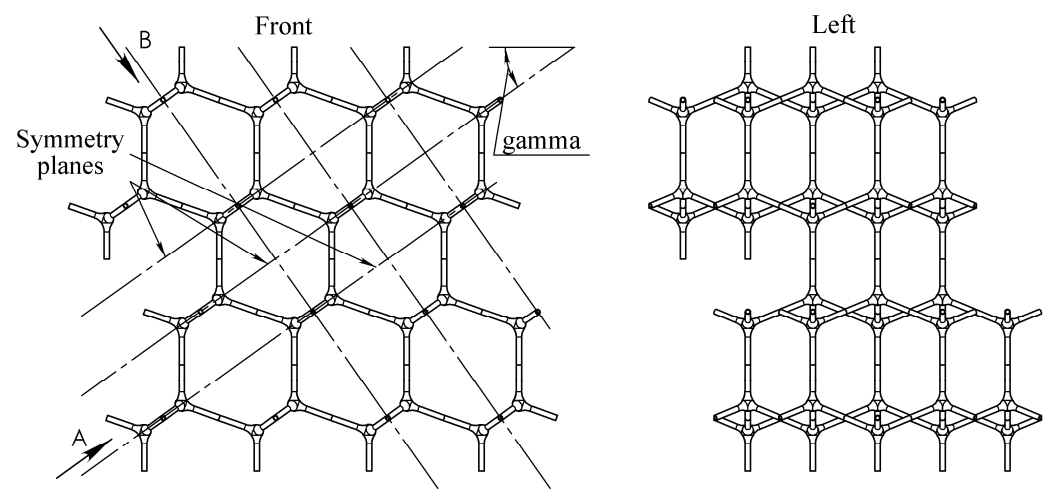

Top
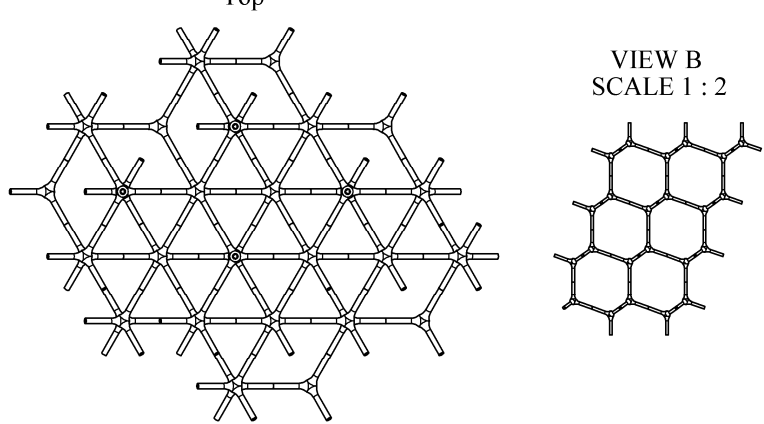

VIEW A

Fig. 4. Two variants of hexagon-type lattices:

a-symmetric with respect to horizontal planes

$\mathrm{b}$ - symmetric with respect to planes at an angle with the top plane 
a)
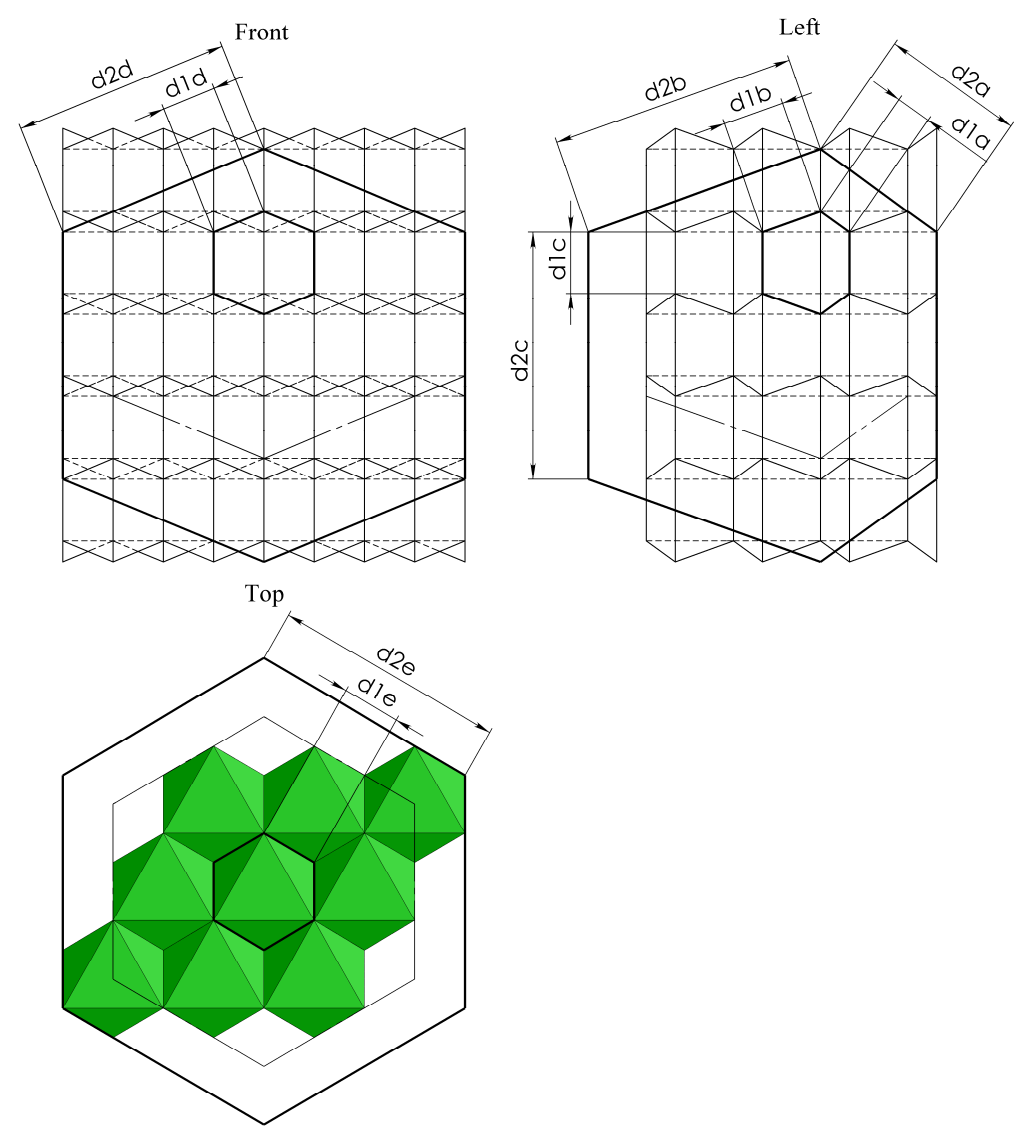

b)
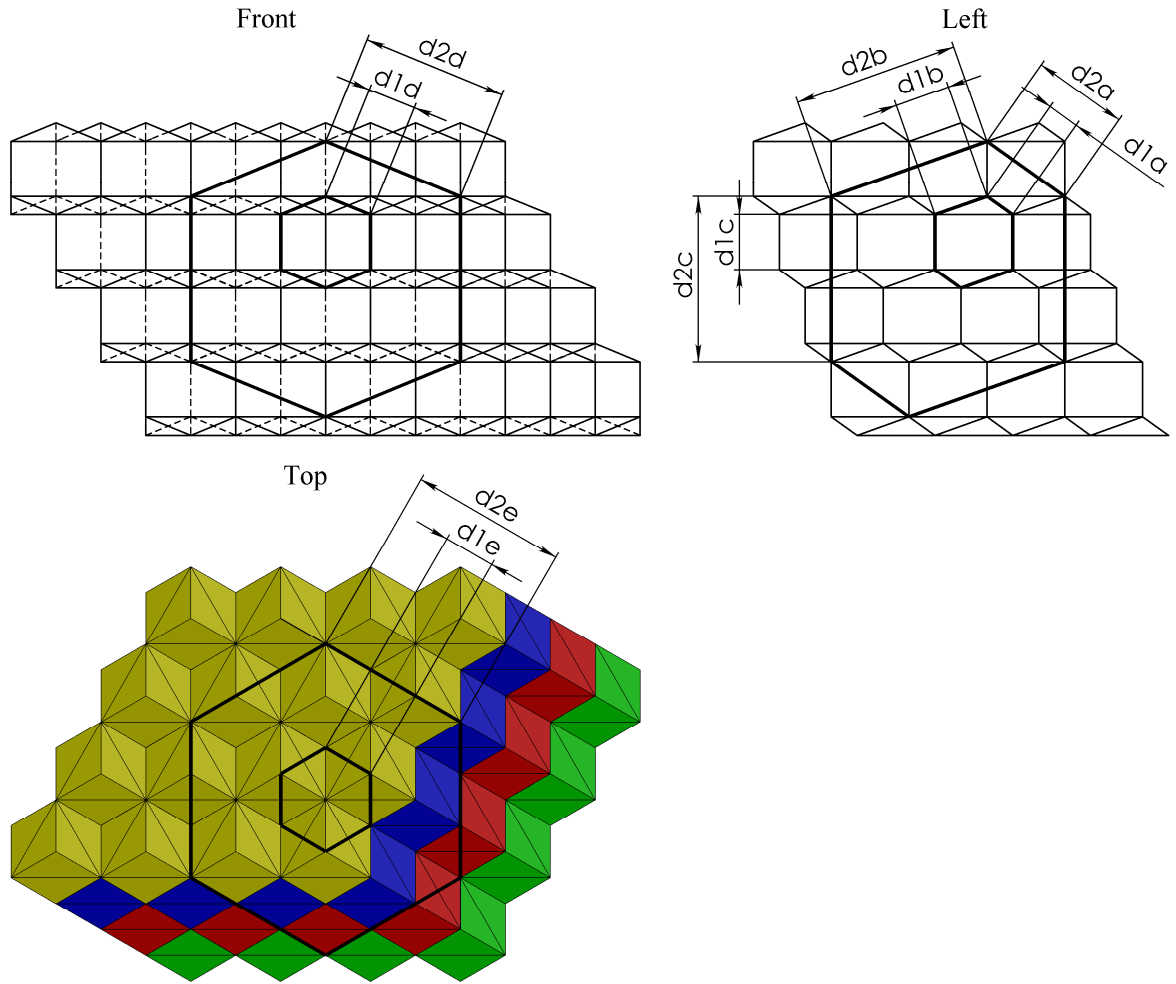

Fig. 5. Two variants of hexagon-type lattices in surface body form: a - symmetric with respect to horizontal planes $\mathrm{b}$ - symmetric with respect to planes at an angle with the top plane 
a)
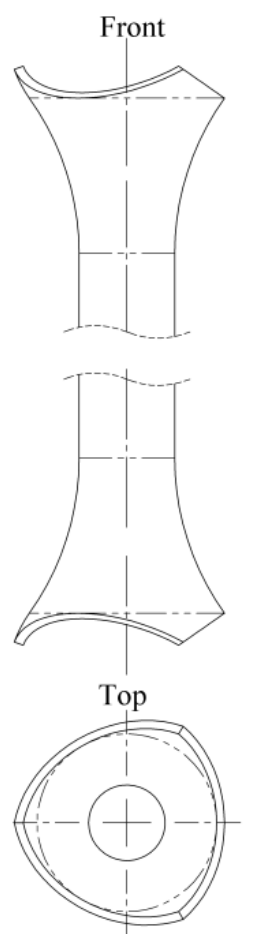

b)
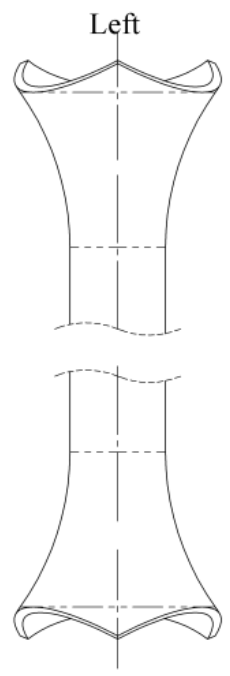
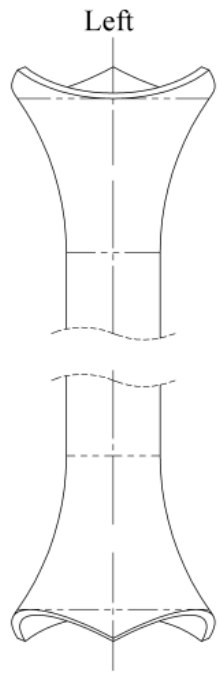

Fig. 6. Two alternative superelement definitions: a - symmetric with respect to a horizontal plane $\mathrm{b}$ - non-symmetric with respect to a horizontal plane
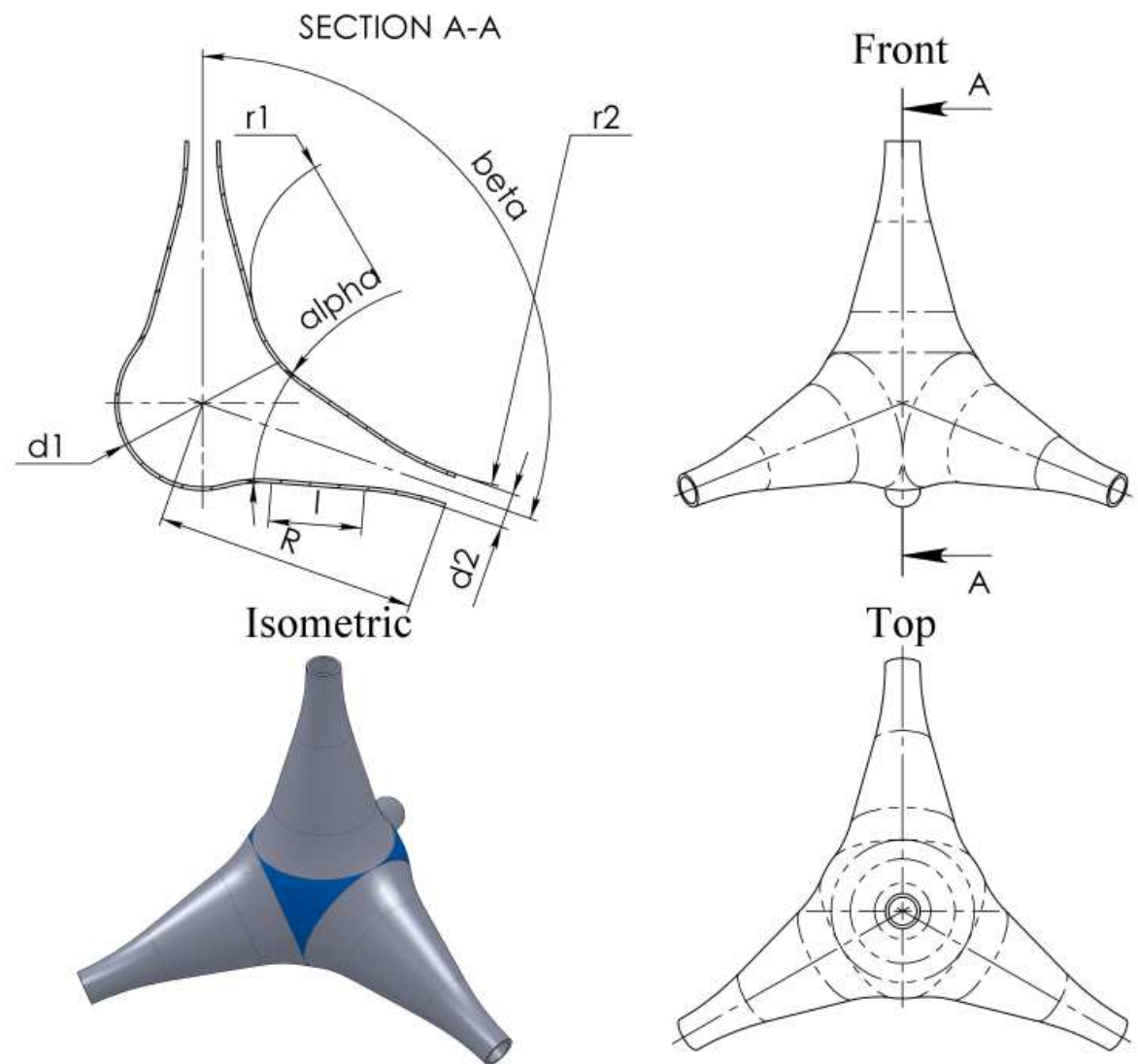

Fig. 7. Superelement shape approximation model and defined parameters 


\section{Conclusions}

- The tetrapod-shaped lattice superelement could be derived by topological transformations of spatially ordered spheres or, alternatively, by an analytic geometric definition of a spatial rayed structure which would have equal angles between any pair of rays. This yields a four-ray star element, also named tetrapod.

- In order to determine the shapes of the regular spatial hexagonal lattices, a combined approach is to use the 2-dimensional hexagonal lattice as a starting point for expanding to three dimensions. This yields two unique spatial hexagon-type cell analogues and, consequently, two lattice variants.

- Considering multiscale tessellation possibility of the lattices, an examination of multiscaled lattice cell vertex coincidence reveals that repeating patterns do exist for the second lattice variant, whereas for the first one full coincidence could not be found within the range of 1:4.

- Due to the two different combination possibilities of the currently defined superelement there can be distinguished two alternative superelements. The first one is unique to the first lattice due to its symmetry with respect to a top parallel plane. The second one is shared by both cell variants as a result of the similarity in the lower parts of both cell variants.

- In order to provide an exact surface shape definition for the superelement, a mechanically determined geometry shape optimization of the superelement should be carried out. This task requires certain assumptions regarding the expected optimum shape of the geometry to be optimized. A specific proposal, which would allow easy parameterization, is to describe the element shape by possibly the simplest geometric shapes that would conform to the initial shape assumptions.

\section{References}

1. Bervalds E. Topological Transformations and Design of Structural Systems // Proceedings of the World Congress on Optimal Design of structural Systems, Vol. 1, August 2-6, 1993. - Rio de Janeiro (Brazil): 1993. - P. 153-160.

2. Bervalds E. Existence of the Phi relationship within a regular hexagonal tessellation // Latvian Journal of Physics and Technical Sciences. - No.2 (2007), P. 57-58.

3. Bervalds E., Dobelis M. Geometric Properties of a Regular Lattice Caused by $\Phi$ Relationship // Proceedings of the $13^{\text {th }}$ International Conference on Geometry and Graphics, August 4-8, 2008. Dresden (Germany): 2008. - 8 P.

4. Bervalds E., Dobelis M., Verners O. Geometric Parameterization of A Tetrapod-Shaped Structural Element // Proceedings of the $10^{\text {th }}$ International Conference on Geometry and Graphics, June 4-5, 2009. - Vilnius (Lithuania): 2009. - P. 24.-29.

5. Yaghi, O.M., O'Keeffe, M., Ockwig, N.W., Chae, H.K., Eddaoudi, M., Kim, J. Reticular synthesis and the design of new materials // Nature. - Vol. 423 (12 June, 2003), P. 705-714.

6. Hyde B.G., Andersson, S. Inorganic crystal structures. - New York: Wiley, 1989. - P. 10, 56.

\section{Bervalds E., Verners O., Dobelis M. Telpiska režğa konstrukcijas no četrzara elementa}

Divi iepriekšēju pētījumu rezultāti l̦auj secināt, ka telpiskas sešstūra tipa režğa struktüras ar regulāra četrzara formas savienojumiem atbilst optimālam režğa un optimālas daudzmērogu režğu divdimensionālas savietojamības risinājumiem. Tomēr pagaidām nav tikusi veikta telpisku režğu topologisku transformāciju un daudzmērogu rě̆ğ telpiskas savietojamības izpēte pēc analogijas ar divdimensionālu problēmas izpēti, kas paveikta lìdz šim. Tādēl raksta mērksis ir iegūt telpiskas sešstūra tipa režğa struktūras un noteikt tās veidojošo šūnu daudzmērogu režğ telpiskas savietojamības iespējas.

Lai noteiktu telpisko rě̆ğ variantus, ir iespējami divi risinājumi. Pirmais ir lietot telpā regulāri novietotu sfēru topoloğiskas transformācijas. Otrais savukārt ir meklēt iespējamās režği veidojošo superelementu kombinācijas. Tomēr abas pieejas rada nepieciešamību pārliecināties, ka visi iespējamie rě̌ğ varianti ir atrasti. Kombinēts risinājums ir izmantot divdimensionālu sěsstūra šūnu režği kā izejas punktu pārejai uz telpisku variantu. Šis 
risinājums ļauj iegūt divus unikālus režğa variantus, ko veido attiecīgi divi telpisko šūnu varianti. Aplūkojot daudzmērogu režğu telpiskas savietojamības iespējas, daudzmērogotu režğus veidojošo šūnu mezgla punktu atbilstības pārbaude atklāj, ka daudzmērogu telpiska savietojamība ir iespējama otrajam režğa variantam.

\section{Bervalds E., Verners O., Dobelis M. The Spatial Lattice Design from a Tetrapod-shaped Element}

Two discoveries demonstrate that hexagon-type spatial rigid bar structures built of tetrapod-shaped superelements are the best for solving of optimal lattice and optimal two dimensional multiscale tessellation problems. Unexplored, however, remain the topological transformations and multiscale tessellation possibilities of regular spatial lattices space in analogy to the 2-dimensional transformations considered so far. Therefore this article concentrates specifically on derivation of hexagon-type spatial lattices and the multiscale tessellation compatibility possibilities of the spatial lattice cells obtained.

In order to determine the shapes of the regular spatial hexagonal lattices, two choices are available. The first one is to apply topological transformations to spheres, placed at regular points in space. The second one is to search for all unique combinations of the superelements. However, both of the approaches ask for proof that all possible lattice configurations have been found. A combined approach is to use the 2-dimensional hexagonal lattice as a starting point for expanding to three dimensions. This yields two unique spatial hexagon-type cell analogues and, consequently, two lattice variants. Considering multiscale tessellation possibility of the lattices, an examination of multiscaled lattice cell vertex coincidence reveals that repeating patterns do exist for the second lattice variant.

\section{Бервалдс Э., Вернерс О., Добелис М. Пространственные решетчатые конструкции из четырех ногих элементов}

Результаты двух прежних исследований показывают, что жесткие объемные гексагональные стерженевые конструкиии с регулярными четырех ногими соединениями являются лучшим подходом к решению проблем оптимизации пространственной решетки и оптимальному упорядочению плоских многомасштабных элементов. Однако, не исследованными пока остаются топологические трансформаџии и возможности многомасштабного упорядочения регулярных и повторяющихся структур в пространстве по аналогии с плоскими трансформациями рассмотренными до сих пор. Поэтому целю настоящей работы является получение пространственных конструкиий типа гексагональных решеток и определение возможности совместимости многомасштабного упорядочения полученных трехмерных ячеек.

Для определения вариантов пространственной решетки существуют два подхода. Первый связан с применением топологических трансформаций сфер, которые регулярно расположены в пространстве. Второй подход в свою очередь связан с поиском всех возможных комбинаций ячеек или суперелементов. Однако оба подхода требуют доказательства того, что все возможные варианты решеток найдены. Комбинированным решением является использование плоской шестигранной решетки как исходной для перехода к объемному варианту. Это решение позволяет получить двух уникальных вариантов решеток, которые образованы из двух вариантов пространственных ячеек, соответственно. Рассматрывая возможности упорядочения многомасштабной решетки, качественный анализ конгруентности узловых точек образуюших многомасштабной решетки позволяет выявить, что многомасштабное пространственное упорядочение возможно для второго варианта решетки. 